\title{
Eradicating Poverty through Zakat Utilization (A Case from Kelompok Bina Zakat Program)
}

\author{
Mail Hilian Batin ${ }^{1 *}$, and Dini Rahmayanti ${ }^{2}$ \\ ${ }^{1}$ Fakultas Ekonomi dan Bisnis Islam, UIN Raden Fatah, Palembang, Indonesia \\ ${ }^{2}$ Fakultas Ekonomi dan Bisnis Islam, IAIN Salatiga, Indonesia
}

\begin{abstract}
Economic inequality is something that is still visible in a developing country. The wide gap between the rich and the poor is a key factor in causing poverty. The National Amil Zakat Agency (BAZNAS) is one of the institutions that aim to collect and distribute zakat funds. In its distribution, BAZNAS formed Kelompok Bina Zakat (KBZ) spread across various regions. The establishment of the KBZ is expected to be a solution to the problem of poverty in Indonesia. This study aims: what is the background of banuayu village and KBZ Program? Can the formation of KBZ be a solution to poverty alleviation? And how the BAZNAS stimulant fund mechanism can develop? This research is a field research with a qualitative descriptive approach. The data collection techniques used are observation, interviews, and documentation. The results show that there is a significant influence on the formation of the KBZ in poverty alleviation with the assistance of venture capital from the BAZNAS stimulant fund, so that the economy of the community in Banuayu OKUT Village, South Sumatra can live. Then the mechanism is to charge a loan principal return of Rp. 100,000 as a profit sharing from borrowed funds of Rp. 1,000,000.
\end{abstract}

Keywords: Poverty, Zakat Utilization, Kelompok Bina Zakat

\section{Introduction}

Poverty is a problem faced by all countries both developed and developing countries including Indonesia.The extent of the island with a variety of natural wealth owned still cannot eliminate the country's economic problems. Economic problems are a fundamental problem that occurs in every region and experienced by all communities. This problem occurs because there is a gap between the rich and the poor, causing symptoms of poverty.

Based on the data of table 1, the number of poor people in 2017 to 2019 tends to decrease. There was an increase in the number of poverty in 2020 , with a total of $26,424.02$. The percentage of the poor population in September 2020 amounted to 10.19 percent, increased by 0.41 percentage points against March 2020 and increased by 0.97 percentage points against September 2019.

\footnotetext{
* Corresponding author: mail.batin uin@ radenfatah.ac.id
} 


\section{$A \mathrm{C} \overline{I E B}$ Annual International Conference \\ on Islamic Economics and Business, 2021}

Table 1. Number of poor people in Indonesia

\begin{tabular}{|c|c|}
\hline Year & Number of poor people (thousand people) \\
\hline $\mathbf{2 0 1 7}$ & 26582.99 \\
\hline $\mathbf{2 0 1 8}$ & 25674.58 \\
\hline $\mathbf{2 0 1 9}$ & 24785.87 \\
\hline $\mathbf{2 0 2 0}$ & $26.424,02$ \\
\hline
\end{tabular}

Source: BPS 2021

Table 2. Number of Poor People in South Sumatra

\begin{tabular}{|c|c|}
\hline Year & Number of poor people (thousand people) \\
\hline $\mathbf{2 0 1 7}$ & 1086,76 \\
\hline $\mathbf{2 0 1 8}$ & 1076.40 \\
\hline $\mathbf{2 0 1 9}$ & 1067.16 \\
\hline $\mathbf{2 0 2 0}$ & 1081,58 \\
\hline
\end{tabular}

Source: BPS 2021

From the data above, we can see the total number of poor people from year to year in South Sumatra has decreased, but in 2020 there is an increase caused by the Covid-19 pandemic, which causes many cases of death and the number of people who lose their jobs and decreases in the recovery of business results.

Islam sees the problem of poverty from three aspects, namely: First, poor spirituality. A human being experiences emptiness in his soul in relation to God, so he always experiences restlessness in his life. Second, lack of knowledge. Someone who does not have knowledge in dealing with life's problems sometimes tends to be careless in acting and lacks a work ethic. Third, poor material. A person who does not have wealth to meet his needs, sometimes his life still depends on others, but has the ability to work to fulfill himself (Arif, 2010).

To measure the welfare of mustahik based on material and spiritual needs, the Center of Islamic Business and Economics Studies (CIBEST) Welfare Index can be used. Individuals are said to be materially capable if their income is above the household poverty line or material value.

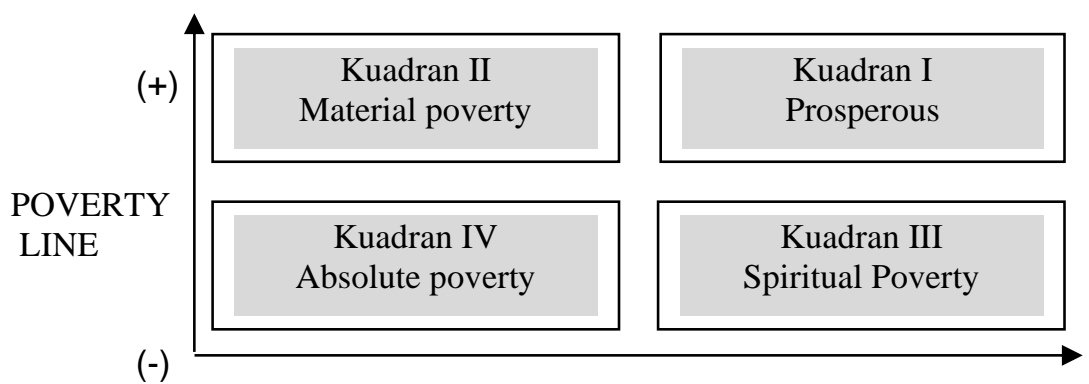

$(-)$

$(+)$

Fig. 1. Cibest Quadran

The CIBEST quadrant divides the household's ability to meet material and spiritual needs into two signs, namely positive (+) and negative (-) signs. The sign $(+)$ means that the household is able to meet its needs well, while the sign (-) means that the household is not able to meet its needs properly. With a pattern like this, four possibilities will be obtained, namely the (+) sign for the fulfillment of both material and spiritual needs, the $(+)$ sign for only one need, whether the $(+)$ sign is for material needs or the $(+)$ sign is for spiritual needs. course, as well as a (-) sign on both material and spiritual needs (Beik \& Arsyianti, 2016).

The government has the right "tools" to collect and distribute zakat from the community in an integrated and large-scale manner, namely through BAZNAS. BAZNAS as a 


\section{$A I \overline{C E B}$ Annual International Conference \\ on Islamic Economics and Business, 2021}

government body that aims as a collection and distribution of zakat funds. BAZNAS is a nonstructural institution formed based on government regulations through article 7 of Law No.23 of 2011 on zakat management, thus strengthening the role of BAZNAS as an institution authorized to manage zakat nationally. In addition to receiving zakat, BAZNAS can receive infaq, alms, and other religious social funds (philanthropy). The purpose of the establishment of BAZNAS contained in article 3(b) is to increase the benefits of zakat to realize community welfare and poverty reduction.

Zakat in general is a form of worship related to financial and community economy.In addition, zakat is also one of the five pillars of Islam that has an important status and function in Islamic shari'ah.One of the functions of zakat is to realize the equalization of justice in the economic field.As one of the Islamic economic institutions, zakat is a potential strategic source of funds for efforts to build the welfare of the ummah (Rofiq, 2012).

The contributing factors of the Islamic community carrying out zakat collection in Indonesia include:

- The desire of Indonesian Muslims to perfect the implementation of their religious teachings. After establishing prayers, fasting during Ramadan and even performing hajj to Mecca, Muslims increasingly realize the need for the use of zakat as a religious obligation; obligations that must be carried out by everyone who is able to carry it out because it has met the specified conditions.

- The growing awareness among Muslims about the potential of zakat if utilized as well as possible will be able to solve various social problems in Indonesia.

- Efforts to realize the development and management of zakat in Indonesia are increasingly growing and developing (Sartika, 2008).

BAZNAS in addition to aiming to collect zakat funds also serves in the distribution of zakat funds to eight asnaf. In its application, so far the presence of zakat is still less impactful for zakat recipients, especially for the poor people. This is motivated by the understanding that zakat in its distribution is still consumptive, so that, when the zakat is completed distributed then the benefits received by mustahiq can only be used in a short period of time, while the purpose of zakat itself is not only limited to consumptive activities, but has a more permanent goal of alleviating poverty through productive zakat (Qadir, 2001).

The utilization of productive zakat actually has the concept of careful planning and implementation such as studying the causes of poverty, the absence of working capital, and lack of employment.With these problems, the need for a proper planning system begins with good planning, good implementation, and good supervision, so that the distribution of zakat becomes effective and efficient.

Rosmawati (2014), the benefits of productive zakat for the economy have also been proven in Yoghi Citra Pratama's research explaining that although zakat funds collected are still very small, but have a real impact in poverty alleviation efforts through productive zakat programs.Zakat becomes an effective financial instrument in the capital problems of the poor. With the development of the potential of productive zakat funds, through guidance and extension for more intensive individual venture capital financing partners, it is expected to improve the quality and competitiveness of partners.

Based on The Background Above, BAZNAS SumSel also functions to distribute zakat funds. In order to distribute these zakat funds, BAZNAZ formed Bina Zakat Groups (KBZ) which are spread in various regions, one of which is in East OKU Regency, precisely in the village of Banuayu. This research will focus on four problems as follows:

- What is the background of banuayu village and Kelompok Bina Zakat BAZNAS Program?

- Can the formation of Kelompok Bina Zakat be a solution to poverty alleviation?

- How the BAZNAS stimulant fund mechanism can develop? 


\section{$A \mathrm{IC} \quad$ Annual International Conference \\ on Islamic Economics and Business, 2021}

\section{Literature Review}

\subsection{Zakat Management Models}

Funds or assets collected through the zakat system are a potential source of funds that can be used to finance productive businesses in the context of improving people's welfare in accordance with the objective conditions of today's world life.

Today's zakat management models have touched various aspects of individual and community life needs. The management model developed is not limited to meeting shortterm needs but is combined with the concept of community empowerment.

Management models that have yielded significant results and benefits for people's lives touched by the zakat empowerment program are, among others, as follows:

- Charitable services in the form of humanitarian assistance oriented towards meeting the urgent needs of life for the poor, providing free health care facilities, critical emergency assistance for disaster areas, fires, conflict areas, riots, and others which are channeled through social service activities. Charitable services also include a compensation program for new converts to Islam who do not have a fixed income.

- Human empowerment, through scholarship/study assistance programs for students who come from underprivileged families and orphans whose parents left without material supplies. The human empowerment program is also realized through the provision of job skills training/professional training for members of the productive age community.

- Empowerment of the people's economy in the form of capital assistance programs for productive businesses and people's industries that are distributed individually and group integration with accompanying staff, independent community programs, and zakat assisted villages. The Ministry of Religion, in this case the Directorate of Zakat and Waqf Development, is currently making a pilot program for zakat-assisted villages spread across each province throughout the country.

- Programs for building or renovating religious facilities (schools and madrasas), orphanages, hospitals, training da'I, and others in order to build the quality of Muslims and improve the welfare of the community as a whole in terms of physical and mental spirituality.

Management of zakat based on Law No.23 of 2011 article 2, is based on: a. Islamic law,

b. Trust, c. Benefits, d. Justice, e. Legal certainty, f. Integrated and g. Accountability.

Article 3, Zakat management also aims to:

- Improving the effectiveness and efficiency of services in the management of zakat.

- Increase the benefits of zakat to realize community welfare and poverty alleviation.

\subsection{Zakat Management Models}

Charity according to language is charity, charity, and generosity. In distributing zakat, the term charity can be used for programs to fulfill the consumptive needs of mustahik, such as food and housing. The term empowerment or utilization is usually used for the distribution of zakat, including the provision of business capital for certain businesses with assistance so that mustahik can manage their businesses and be independent.

Among the characteristics of charity programs are that there are no follow-up, consumptive, and short-term programs, such as food assistance and shelters. The characteristics of the empowerment program are that there are follow-up, productive, and long-term programs, such as programs to improve children's nutrition and independent families (Sahroni et al., 2018). 


\subsubsection{Policies in the Utilization of Zakat Distribution Consists of Distribution and Utilization}

- Distribution and utilization for the eight asnaf

- Emphasis on the poor asnaf

- To meet the basic needs of food, shelter, health and education

- Food or money assistance can be done monthly or Islamic holidays assistance

- For the needs of the village to build poverty alleviation

- Educational assistance in the form of scholarships

- Help empowering the people's economy

\subsubsection{Consumptive Distribution}

Utilization of zakat is intended to fulfill the needs of the mustahiq eight asnaf which in its application can include people who are the most economically helpless, such as orphans, the elderly, and people with disabilities, people who are studying, Islamic boarding schools, abandoned children, and victims of natural disaster. Distribution of zakat to them is a temporary aid to solve urgent problems

\subsubsection{Productive Utilization}

Utilization of zakat can be allocated for productive businesses, if the mustahiq needs of the eight asnaf have been met and there are advantages.Utilization of infaq, shadaqah, grants, wills, inheritance, and kafarat funds is prioritized for productive businesses in order to improve the welfare of the community. The distribution of zakat in this form is in the form of empowerment assistance through sustainable programs or activities.

Zakat that is used to run a business with full awareness in order to get profits or in the form of profit sharing can be interpreted as productive zakat or productive zakat. Productive zakat is zakat in which the assets or zakat funds given to mustahik are not spent but are developed and used to help their businesses, so that with these efforts they can meet the needs of life continuously (Asnaini, 2008).

The utilization of zakat must have a positive impact on mustahiq, both economically and socially. From the economic side, mustahiq are required to be truly independent and live decently, while from the social side, mustahiq are required to live on an equal footing with other communities. This means that zakat is not only distributed for consumptive things and is only charitable, but more for productive and educational purposes.

The model for the utilization of zakat for economic empowerment of the poor is a program to utilize zakat funds to encourage mustahik to be able to have independent businesses. The program is realized in the form of developing existing micro-enterprise capital or pioneering new micro-enterprises with prospects.

The utilization process as above goes through stages that remain in accordance with the provisions of the legislation, namely:

- Registration of potential beneficiaries

- Feasibility survey

- Grouping strategy

- Accompaniment

- Periodic coaching

- Engaging third party partners

- Supervision, control and evaluation

The government has also regulated the utilization of zakat funds, as stated in Law No. 23 of 2011 article 27, namely: 


\section{$A I \overline{I E B} \quad$ Annual International Conference \\ on Islamic Economics and Business, 2021}

- Zakat can be utilized for productive efforts in the context of handling the poor and improving the quality of the people.

- Utilization of zakat for productive business is carried out if the basic needs of mustahik have been met.

- Provisions regarding the utilization of zakat for productive businesses are regulated by a Ministerial Regulation.

\subsection{Function of Zakat Institution and Zakat on the Society Economy}

The function of zakat institutions is specifically according to the Law that zakat management is carried out by the national amil zakat agency and amil zakat institution.The arrangement of the establishment of zakat management institutions is indeed important considering the potential of zakat in Indonesia, which is majority Muslim, of course, is large.Zakat management institutions are mentioned by the terms of Amil Zakat Agency and Amil Zakat Institution.The National Amil Zakat Agency (hereinafter abbreviated as BAZNAS) is an organization formed by the Government and manages zakat nationally. BAZNAS is based in the capital of the country and each district / city has a branch of BAZNAS (Pasal 5 dan pasal 6 Undang-undang Nomor 23 Tahun 2011).

In public life the term zakat is very well known to the community, especially among Muslims. Zakat is also understood as expenditure (consumption) for the owner of the property so that the economic capabilities he has.In terms of language, according to the Arabic word, the word zakat is the basic word (masdar) of zakat which means holy, blessed, growing, and praiseworthy, all of which are used in translating the Qur'an and hadith (Muhammad \& Mas'ud, 2005). Zakat according to terminology or term, means the right that must be removed from the property. The treasure is called zakat, because it will increase and preserve from destruction. While other understanding as contained in the law, zakat is a property that must be issued by a Muslim or business entity to be given to those who are entitled to receive it in accordance with Islamic sharia. Sahroni et al. (2018), zakat issued when it has reached its haul or when harvesting with a certain value $(2.5 \%, 5 \%, 10 \%$, or $20 \%)$ and certain targets (fakir, poor, amil, convert, riqab, gharim, fisabilillah, and ibn sabil).

In the Qur'an there are 32 words zakat (الز كاة), even as many as 82 times repeated by using words synonymous with it, namely almsgiving and infak. Repetition means that zakat has a very important position, function and role (Qadir, 2001). Of the 32 words of zakat contained in the Qur'an, 29 of them go hand in hand with the word Salat. This indicates the close relationship between zakat worship and prayer. Prayer is the embodiment of relationship with God, while zakat is the embodiment of relationship with God and fellow human beings.

The Qur'an on zakat was revealed in two periods, namely the mecca period of eight verses, among which is contained in surah 73 /Al-Muzammil verse 20.

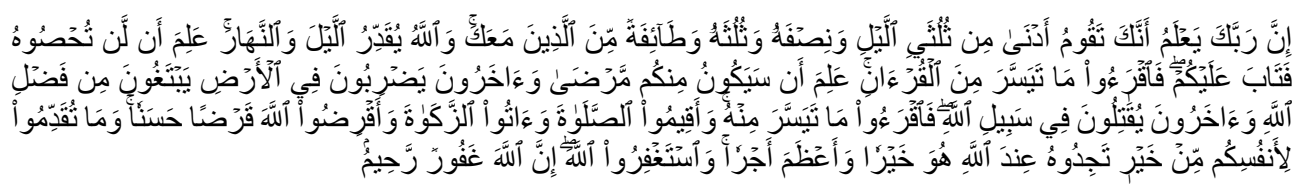

“...and establish prayer and give zakāh and loan Allāh a goodly loan. (Al-Muzammil, 73:20)

And in letter 98/Al-Bayyinah verse 5:

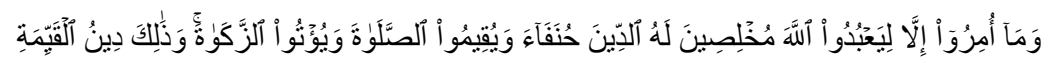




\section{$A \mathrm{I} \overline{I E B}$ Annual International Conference \\ on Islamic Economics and Business, 2021}

"... and to establish prayer and to give zakāh. And that is the correct religion..." (Al-Bayyinah, 98:5)

The rest of the verses on zakat were revealed in the Medina period.The verses about zakat are contained in various letters, among others in surah Al-Baqarah verse 43:

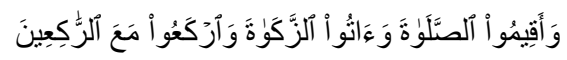

"And establish prayer and give zakāh[24] and bow with those who bow [in worship and obedience]." (Al-Baqarah, 2: 43)

And in surah 5/Al-Maidah verse 12:

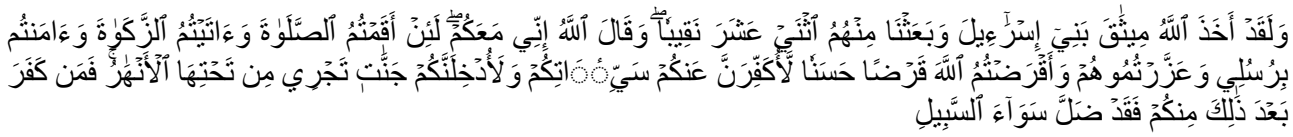

"...I am with you. If you establish prayer and give zakāh and believe in My messengers..." (Al-Maidah, 5:12)

The zakat commandment handed down in the Mecca period, as contained in the two verses above, is only a recommendation to do good to the poor and those who need help. While being handed down in the Medina period, the order has become an absolute obligation.

Sahroni et al. (2018) among some of these words, the legal basis regarding zakat is also contained in a hadith, namely:

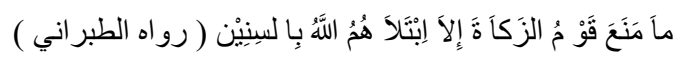

"If a people refuse to release zakat, Allah will test them with drought and famine." (HR Thabrani)

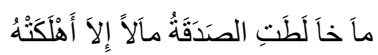

"If zakat is mixed with other treasures, it will destroy the treasure." (HR.Al-Bazar and Baihaqi)

Based on some of the above understandings, it can be concluded that the advice to berzakat has existed since ancient times. The advice is mandatory because some of the property owned has the right of the poor. The property must be issued and distributed to the person who is entitled to receive it.

Zakat has an important role to play in economic problems. The basic problem is the lack of sufficient capital. Capital in this case money is an instrument that is no less important for all people both rich and poor. Poverty is the result of insufficient capital. Poverty occurs because of unavailability of work or unavailability of capital to strive. This gives rise to the phenomenon of unemployment.

Qaradhawi (2005), the phenomenon of high unemployment is not a small problem, if not immediately overcome it will be bad for the lives of individuals, families, and also society in general. Below are some of the adverse effects of unemployment, namely:

- Economically; have no income or income.

- Health; It will reduce body movement and footsteps.

- Mentally; It will make a person live in a vacuum of time.

- Socially; Envy and malicious for the success of others. 


\section{$A I \overline{C E B}$ Annual International Conference \\ on Islamic Economics and Business, 2021}

With the above adverse effects, it is natural that Islam hates unemployment. Therefore, it is commanded to every Muslim to be able to work and earn on this earth; all work and efforts are carried out as a form of worship and jihad in the way of Allah, when accompanied by good intentions and strong money beliefs and responsibilities. The Prophet himself mentioned in front of his companions, that he and also some other apostles who are messengers of Allah also worked in sufficient life; As a goat herder, as did Moses and other prophets.The Prophet said: "There is no better food for a person, but what is produced from the work of his own hands" (H.R. Bukhari).

Based on the above explanation it can be concluded that the role of zakat in eradicating unemployment is to increase productive labor, although this seems impossible or far from some contemporary thoughts that exist today, especially for those who have not studied the nature of zakat.

Many studies related to zakat can alleviate poverty, including: (Sari et al., 2019), Investigating the Impact of Zakat on Poverty Alleviation analysis using the indicators of the Headcount Ratio Index, the Poverty Depth Index and the Poverty Severity Index, shows that zakat can reduce poverty in West Sumatra, Indonesia. It may also be seen that with zakat, the underprivileged community can get out of poverty faster, than those of without zakat. In this regard, the government can optimise the collection of zakat funds in West Sumatra to best target in realising its potential and supporting the local agenda of poverty alleviation. In the province, Zakat fund which has been collected reached Rp. 1.7 trillion, which falls short from the expected potential amount. Likewise, zakat institutions are recommended to keep and improve their innovation in empowering Mustahik.

Research on zakat as a community development instrument was carried out by Mochlasin (2015) by title Community Development Dengan Instrumen Zakat Profesi Di Desa Jumoyo, Kecamatan Salam, Kabupaten Magelang. The result, community development is intended to create the independence of local communities to organize their own socio-economic, so that their dependence on the state is reduced. Observing the practice of professional zakat management in Jumoyo Lor Hamlet, there has been community empowerment by relying on their own strength. At least the basic needs of rice, health and education have been tried to be met by the community themselves, although at a very minimal level.

The benefits related to zakat funds on the empowerment of traders are also felt, as research Haidir (2019) with the title Revitalizing the Distribution of Productive Zakat as an Effort to Alleviate Poverty in the Modern Era. The granting of capital loan assistance amounting to Rp. 5.000.000,- which was given by BAZNAS Yogyakarta City to 80 small entrepreneurs who were divided into 3 types of businesses, namely 32 people angkringan business, 20 people fried food business and 28 cellular businesses. These small entrepreneurs trade around the city of Yogyakarta on average from morning to night, either by using a cart or renting a kiosk for selling locations. As a result, the distribution of productive zakat in the form of business capital has a positive impact on mustahik in improving their standard of living. The productive zakat distribution program has also been able to create new jobs for the surrounding community, and has been able to create human resources that have high creativity and competitiveness.

Recent research conducted by Kholis \& Mugiyati (2021) about Distribution of Productive Zakat for Reducing Urban Poverty in Indonesia. This study aims to explore the mechanism by which BAZNAS manages productive zakat in an attempt to help alleviate poverty in Indonesia. The results showed that to reduce the poverty of the urban poor, the BAZNAS applies a strategic distribution of productive zakat implemented through: (1) A revolving capital loan to increase venture capital of the mustahiq members of MSMEs run under the qard al-hasan contract. (2) Providing work equipment for starting or developing businesses.

These mechanisms were effective in helping the poor for starting and expanding their business, hereby improving their wellbeing. It is suggested that amil zakat may increase the 


\section{$A \mathrm{IC} \overline{I E B}$ Annual International Conference \\ on Islamic Economics and Business, 2021}

allocation of zakat distribution for productive purposes, rather than for one stop consumption. This study expands the understanding of the currently developed approach to zakat management and provides sound good practices in reducing poverty. From previous studies, it has not been found regarding the research of the Kelompok Bina Zakat Program.

This figure will describe and showing a framework in this research:

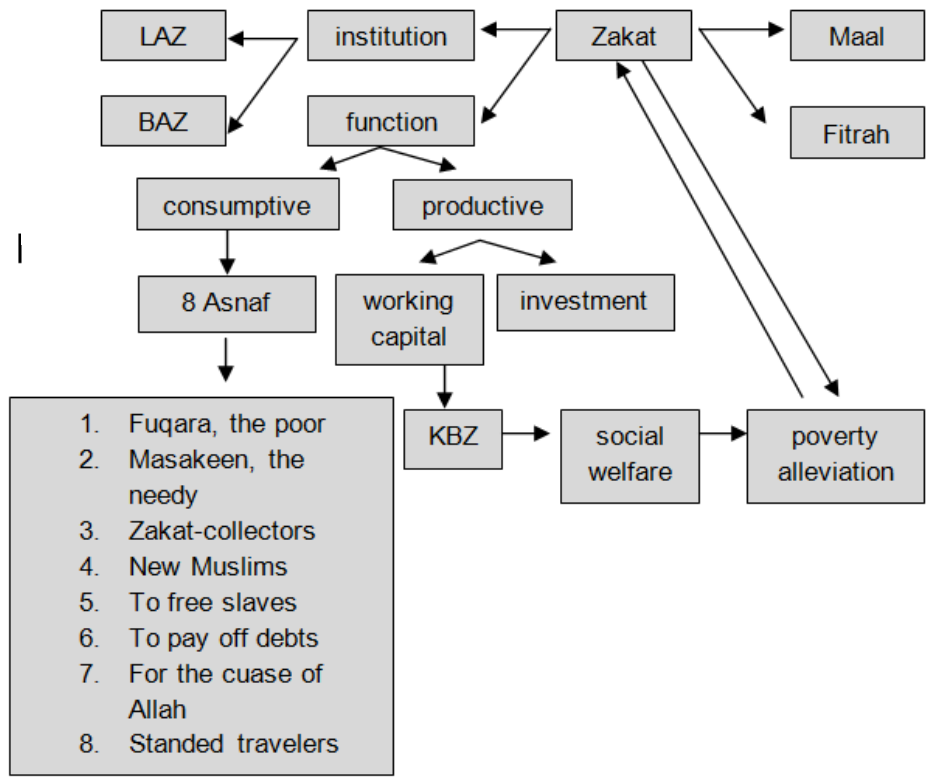

Fig. 2. Framework

\section{Method}

The type of research used is descriptive qualitative, namely research that seeks to describe a symptom, event, event that is happening now. This study focuses on the actual problem as it was at the time the research took place. Descriptive research has steps that begin with a problem, determine the type of information needed, determine the procedure for collecting data through observation or observation, processing information or data, and drawing a conclusion (Noor, 2016). While the nature of this research is informative, it is said to be informative because the results of this research are expected to contribute information for related parties and especially for readers.

The object of the research is the community of Bina Zakat Group (KBZ) in Banuayu Village, East OKU Regency with data collection through observation, interviews, and other supporting reports. While the data analysis process re-explained the results of interviews with the BAZNAS Dai in Banuayu, the Chair of the KBZ, and the community receiving the program. Then secondary data was taken through books, brochures and articles obtained from websites related to this research.

\section{Result and Discussion}




\section{$A \mathrm{IC} \quad$ Annual International Conference \\ on Islamic Economics and Business, 2021}

\subsection{Background of Banuayu Village and KBZ Baznas Program}

The Province of South Sumatra consists of 17 district/city governments, with the number of villages in 2024. From an economic perspective, the rural communities of South Sumatra have a relatively good standard of living. This is due to the support of its natural conditions which are quite fertile. Rural communities who own rice fields, rubber plantations, oil palm, pepper and coffee, were economically able to withstand the onslaught of the economic and monetary crisis in 1998.

The fairly good economic growth in the past has pushed the pace of development of people's life patterns on the one hand, but on the other hand (education and religion) is relatively unbalanced. The atmosphere of religious life in society seems to have been neglected. The prevalence of development programs and the de facto modernization process which emphasizes success in the economic sector has resulted in a shift in the orientation of the community to a tendency to emphasize and prioritize consumptive, economic and material things. This reality has an impact on the attitudes and mindset of rural communities in general. This mindset also influences the community's concern for activities and improving religious life in their village. As an indicator, it can be said that in a number of villages surveyed, there were no religious education institutions at the level of Madrasah Diniyyah, though. Madrasah Diniyah is the basis of community religious education.

Based on this fact, in general it can be concluded that several villages in the South Sumatra Province have become religiously poor villages. This condition certainly invites those who have concern for the importance of awareness and practice of religious teachings, to act and carry out efforts that can elevate the religious life of the community in a programmed and structured manner in the form of sustainable programs.

The National Amil Zakat Agency (BAZNAS) of South Sumatra Province as one of the institutions that manages people's funds in the form of Zakat, Infaq and Shadaqah (ZIS) funds collected from aghniya' at the South Sumatra Province level through the South Sumatra Taqwa Program sees the need to spread preachers to provide guidance religion-based society in order to improve the quality of faith and piety of the people in rural areas within the province of South Sumatra by collaborating with various related parties in a planned, sustainable and integrated manner.

The relationship in this research, starting from the South Sumatra BAZNAS program, by making the South Sumatra Taqwa program, namely by sending da'I to remote areas throughout the cities and regencies in South Sumatra, the program was named Tebar Da'i BAZNAS South Sumatra Province, an efforts to encourage community participation in building a religion-based village community.

The Da'I Spreading Program started in 2010 with the intention of being an effort to empower the community through a program to improve the quality of religious life and improve people's living standards which are carried out in a planned, continuous and integrated manner.

The program began by coordinating with district BAZNAS, one of which was to determine villages that were ready to be assigned to da'I, so specifically for East OKU District, Banuayu village was selected for reasons of lack of religious understanding and population density.

East OKU (Ogan Komering Ulu) regency is a mostly comering area, although some are Javanese, because this place is one of the object areas of the transmigration program in the era of president Suharto, but not all of them from transmigration, such as in Banuayu the dominant community is Java, and from the results of interviews they are immigrants from Pacitan East Java, with the aim of them moving to seek economic improvement, So with some recommendations that have lived in the village, then come to both find work. 


\section{$A \mathrm{IC} \quad$ Annual International Conference \\ on Islamic Economics and Business, 2021}

East OKU regency is an area located in The Province of South Sumatra with martapura capital and has 20 sub-districts, this regency was formed based on Law No. 23 of 2003 is an expansion area of Ogan Komering Ulu Regency.The area of east OKU regency is $3370 \mathrm{Km} 2$, in 2003 this district still consists of 16 sub-districts with a population of 575,410 people with an average of 107 people / Km2 (www.okutimur.go.id, Accessed Sept 25, 2021).

At the beginning of the establishment of East OKU Regency consisted of 10 subdistricts, 199 villages and 3 urban villages and currently East OKU there are 20 subdistricts, 305 villages, 7 urban villages and 20 preparatory villages, with a population of 656.568 .

The main tasks of the da'I from the Implementation of Village Community Development are:

a. Conducting comprehensive data collection on people's lives, namely observing geographical conditions, population, village potential, socio-cultural life which is thought to have an effect on the religious life of the community.

b. Formulating problems in the village based on a scientific approach; planning integrated cooperation with the government and related agencies.

c. Appointing community assistants who will carry out community empowerment functions in the village in the business fields:

1) The socio-religious sector includes:

- Organizing recitations for all ages;

- Organizing activities to commemorate Islamic holidays (PHBI);

- Organizing the Musabaqah Al-Qur'an and other competitions at the village level;

- Motivating the community in building, repairing houses of worship and education;

- Assist the community in carrying out religious activities related to Walimatu Tasmiyah, Walimatu Circumcision, Walimah Marriage, death, and others;

- Recruiting young people to be educated as implementing cadres, leaders of religious ceremonies.

2) The field of Life Welfare Improvement includes:

- Approaching village and sub-district governments to improve facilities, provide social facilities, repair and provide sanitation by first preparing community participation;

- Forming community groups to be directed to become Zakat Assistance Groups (KBZ), which are given a rolling stimulant by first approaching the District Government/Regency/City Government or other related agencies.

To implement the above program, several stages of activities will be carried out, namely:

1. Program preparation in terms of both technical and program substance.

2. Debriefing the Da'i's Power.

3. Social approach in the village while collecting data.

4. Program planning with the community.

5. Implementation of guidance, counseling, training and coordination activities.

6. Monitoring the program running.

By referring to the BAZNAS module, namely forming community groups to be directed to become Zakat Assistance Groups (KBZ), which are given a rolling stimulant by first approaching the District Government/Regency/City Government or other related agencies.

So the Bina Zakat Group was formed in accordance with the South Sumatra National Amil Zakat Agency (BAZNAS) guidebook, which is the essence of the Implementation of Village Community Development, because as the main task of a BAZNAS preacher at the end of the program, suggestions for establishing a decision letter from the Office of Religious Affairs (KUA) of each sub-district are formed each program. 


\section{$A I \overline{I E B}$ Annual International Conference \\ on Islamic Economics and Business, 2021}

The objectives of the Village Community Empowerment program are:

- Prepare community participation in the process of improving religious social life and improving living welfare.

- Provide guidance and counseling to village communities so that they are able to carry out daily mandatory worship activities, carry out religious ceremonies, hold youth development activities to become Islamic youth cadres.

- Develop various fields of economic business for rural communities in order to increase productivity, income levels as a basis for community self-help.

- Fostering and mobilizing the potential of the people in rural areas in order to build and create welfare living together as members of society within the framework of the nation and state of the Republic of Indonesia.

As for the list of names and placements for the location of the Village Workers Assisted by the Amil Zakat Agency of South Sumatra Province Phase I of 2012, namely:

Tabel 3. List of DAI names 2012

\begin{tabular}{|c|l|l|l|l|}
\hline No & Name & Desa/Kelurahan & District & Regency/City \\
\hline 1 & Agus Sumarlin, S.Hi & Bayur Sugihan & Muara Dua Kisam & OKU Selatan \\
\hline 2 & Ruslan, S.Pd.I & Ulak Agung Ilir & Muara Dua Kisam & OKU Selatan \\
\hline 3 & H. Ahirman, S.Ag & Pangkalan Benteng & Talang Kelapa & Banyuasin \\
\hline 4 & Rupiansyah, S.Hi & Muara Telang Marga & Muara Telang & Banyuasin \\
\hline 5 & Sardiana, S.Sos.I & PuloKerto & Gandus & Palembang \\
\hline 6 & M. Umar & Keramasan & Kertapati & Palembang \\
\hline 7 & Supratman, S.Ag & Tabagindo & Selangit & MURA \\
\hline 8 & Irwanto, S.Pd.I & Pasenan & Terawas & MURA \\
\hline 9 & DediIrawan, S.Sos.I & Muara Lintang Baru & Pendopo & Empat Lawang \\
\hline 10 & SyamsulAlwi, S.Sos.I & Padang Gelai & Pasmah Air Keruh & Empat Lawang \\
\hline 11 & Supriyadi, S.Pd.I & Pangkalan Sakti & Air Sugihan & OKI \\
\hline 12 & Hasbullah & Tanjung Baru & Muara Belida & Muara Enim \\
\hline 13 & Haryadi, S.H.I & Muncak Kabau & Bp Bangun Raja & OKU Timur \\
\hline 14 & Abubakar Sidik, S.H.I & Banu Ayu & Bp Peliung & OKU Timur \\
\hline 15 & Herman, S.Ag & Gunung Megang & Gunung Megang & Muara Enim \\
& & Luar & Lempuing Jaya & OKI \\
\hline 16 & M. Yusuf & Lubuk Seberuk & Mana \\
\hline
\end{tabular}

Source: National Amil Zakat Agency (BAZNAS) South Sumatra

\subsection{KBZ Be A Solution to Poverty Alleviation}

The purpose of establishing the KBZ is first, to develop various fields of economic business for rural communities in order to increase productivity, income levels as a basis for community self-help and second, to improve living welfare.

As for the beginning of the formation of the KBZ in the village of Banuayu, namely the deliberations of youth shops, the initial period was elected as chairman of Mr. Mat Zaini, S.Pd.I with a term of office of 5 (five) years from 2013 to 2017.

Judging from the management structure, Mr. Matzaini, S.Pd.I was trusted again by the people of Banuayu village. This reason was also emphasized after the author directly interviewed why he was re-elected, the answer was that the results of the acclamation meeting chose the inkamben on the basis:

- Already have experience in leading;

- Have high loyalty to the development of KBZ; and

- Having high mobility, it is proven that almost every year they always apply for additional funds to BAZNAS Sumsel. 


\section{$A \mathrm{C} \overline{I E B}$ Annual International Conference \\ on Islamic Economics and Business, 2021}

While in the second period 2018-2022 for the management of the Banuayu Village KBZ, namely;

Table 4. List of KBZ Management in Banuayu Village

\begin{tabular}{|c|l|l|}
\hline No & \multicolumn{1}{|c|}{ Name } & \multicolumn{1}{c|}{ Position } \\
\hline $\mathbf{1}$ & Madzaini, S.Pd.I & Chairman \\
\hline $\mathbf{2}$ & Muhchin Akip, S.Pd & Treasurer \\
\hline $\mathbf{3}$ & Taryono, S.Pd & Secretary \\
\hline $\mathbf{4}$ & M. Soleh & Penyuluh \\
\hline $\mathbf{5}$ & Andi Yusuf & Public Relations \\
\hline $\mathbf{6}$ & Mugiono & Public Relations \\
\hline $\mathbf{7}$ & Sa'an Anwar & Member \\
\hline $\mathbf{8}$ & Muntamah & Member \\
\hline $\mathbf{9}$ & Imran Hamzah & Member \\
\hline $\mathbf{1 0}$ & Ahmad Daem & Member \\
\hline
\end{tabular}

Over time, in 2012 in accordance with the direction of the Provincial BAZNAS contained in the spread dai guidebook, with the end of the program forming a Zakat Bina Group (KBZ) by being given funds for each village of $\mathrm{Rp} .10,000,000$, then if in the distribution of zakat funds in 2012 it reached Rp. 160,000,000, as for the distribution system through the Bina Zakat Group formed by BAZNAS Da'i.

The funds are distributed after the end of the spread dai program, because the program lasts for 6 months, with the materials delivered in accordance with the direction of BAZNAS, as for the program materials designed for the development of this village community involving many relevant agencies, so cooperation is needed in this stage. operational. These programs include:

- Development of religious life;

- Institutions and Education (children, youth and adults);

- Socio-economic development (cooperatives, entrepreneurship, home industry);

- Training of village builder cadres (recruited from the village community);

However, of the four programs, in accordance with the principle of priority scale, at the implementation stage it will be adjusted to the village situation map based on a survey conducted by the implementer.

The description of the program is as follows:

Table 5. Economic Empowerment Program

\begin{tabular}{|c|c|c|}
\hline GOAL & STEPS & RESULTS \\
\hline $\begin{array}{l}\text { Improving } \\
\text { people's welfare. }\end{array}$ & $\begin{array}{l}\text { 1. Motivate and promote home } \\
\text { industry activities. } \\
\text { 2. Comparative studies to } \\
\text { regions/provinces where the } \\
\text { fields of religious life, } \\
\text { education and economy are } \\
\text { already advanced. } \\
\text { 3. Turning on the generosity of } \\
\text { the ummah as one } \\
\text { congregation. }\end{array}$ & $\begin{array}{l}\text { 1. Growing entrepreneurial attitude } \\
\text { among the community. } \\
\text { 2. Availability of quality } \\
\text { cooperative and entrepreneurial } \\
\text { management cadres. } \\
\text { 3. Empowerment of KBZ with } \\
\text { modern management and } \\
\text { managed by professionals. }\end{array}$ \\
\hline
\end{tabular}

Source: South Sumatra BAZNAS Guide Module

From the program, the material presented refers to the understanding of the community so that they are able to empower KBZ with modern management and are 


\section{$A I C \overline{I E B}$ Annual International Conference \\ on Islamic Economics and Business, 2021}

managed by professionals, so in the selection of KBZ management (HR) those who have a high level of education are prioritized.

The Zakat Fund Distribution System is as follows:

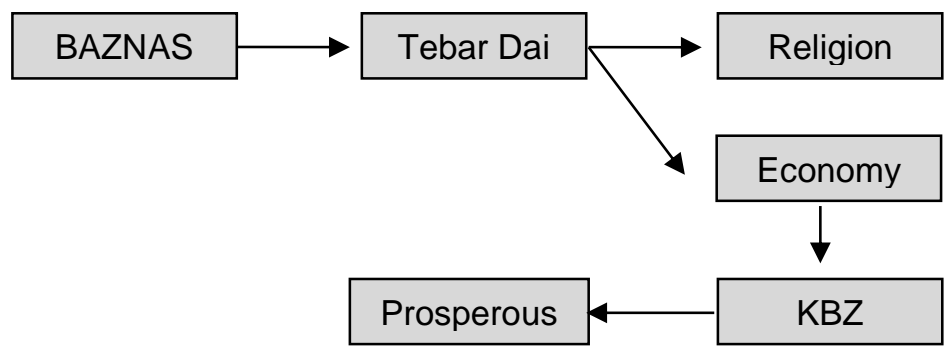

Fig.3 Zakat Fund Distribution System

The picture above explains that the presence of KBZ can be a solution to poverty alleviation. Poverty occurs due to the absence of work so unemployed. The presence of spreading dai is a bridge in improving religion and also the economic system of the community. there is an impact due to:

- The purpose of the formation of the zakat development group is as a forum for distributing zakat funds productively, so that the community can use these funds as an addition to business capital or form other businesses, so that there is economic independence. Another goal is as an amil institution that receives zakat or infaq.

- The zakat funds distributed through KBZ in their empowerment assistance are revolving funds, the funds provided by the manager to Mustahik with a note that they must be qardhul hasan and the utilization of the zakat funds is creative productive empowerment, namely this empowerment is realized in the form of capital that can be used to increase the capital of a trader. or small entrepreneurs. Because on average the people of Banuayu village use their funds to increase capital for making bricks business. This is in accordance with the module guidelines and BAZNAS, namely developing the potential that exists in the village.

Based on the description above, it can be concluded that some of the positive impacts of the existence of zakat funds are:

- The people of Banuayu Village feel helped when they have difficulty with business capital.

- Usually borrowing from a bank carries a fairly large risk, but it is different with the capital from the Bina Zakat Group that uses a qardul Hasan contract, which is to return the principal without any excess beyond the requirements.

- At first the community had limited land for farming, because the majority of the population was trans Javanese. Therefore, the people of Banuayu Village rely on the business of making bricks as their main livelihood. What's more, it requires a decent amount of capital, but because of the existence of KBZ, everyone feels it is easier.

\subsection{Factors that cause KBZ Zakat Funds to Grow}

The utilization of zakat must have a positive impact on mustahiq, both economically and socially. From the economic side, mustahiq are required to be truly independent and live decently while from the social side, mustahiq are required to live on an equal footing with other communities. This means that zakat is not only distributed for consumptive things and is only charitable, but more for productive and educational purposes. 


\section{$A \bar{C} \overline{I E B} \quad$ Annual International Conference \\ on Islamic Economics and Business, 2021}

The main weakness of the poor and the small businesses they do is actually not solely on the lack of capital, but rather on the mental attitude and readiness of business management. For this reason, productive business zakat in the early stages must be able to educate mustahiq so that they are truly ready to change. Because it is impossible for poverty to change unless it starts from the mental changes of the poor themselves. This is called the empowerment role. Zakat that can be collected in the long term must be able to empower mustahiq to the plains of business development. Consumptive programs only function as stimulants and are short term, while empowerment programs must be prioritized. The meaning of empowerment in a broad sense is to make partners independent, so partners in this case mustahiq do not always depend on amil (Sartika, 2008).

The revolving fund management system is Rp. 10,000,000 as a simultaneous fund, namely, each community can only borrow Rp. 1,000,000 and is allowed 2 borrowings and the money is returned after every 3 months along with the infaq of Rp. 100,000 with no coercion, with the aim that other people can borrow (Matzaini, Chaiman of KBZ desa Banuayu, 07 Oktober 2020).

Previously, the principal loan scheme was returned for 3 months and the zakat was returned, but after monitoring the evaluation from BAZNAS, it was considered that the income from the brick business every time it burned did not reach the nisob, then the scheme was replaced with an infaq. Why is it considered infaq because there are some who borrow only to return the principal loan (Muhchin, 2020).

In addition, the loan funds are not used as a business capital such as a debt scheme if they are unable to pay it, but only loans based on mutual assistance and for the borrower to be given an understanding to have a responsibility to carry out the mandate as a borrower, why is it not considered a debt because the status of the fund is zakat. Like the case of the borrower on behalf of Mr. Betok (pseudonym) on April 7, 2017, he could not pay and also had a lot of debt to other parties, so it was considered that the loan was accepted from the KBZ and considered as assistance for the poor.

So it can be understood from the zakat fund management system in the KBZ of Banuayu village that it prioritizes the principle of trust for revolving fund borrowers, because it does not require collateral in case of late payments, only holds trust between the two parties.

Based on the results of interviews regarding the KZB management system, they are as follows:

a. Bangunrejo village is known for its quality brick industry, the majority of its residents depend on this business for their lives.

b. The presence of the BAZ assistance fund is very useful, with this assistance it can increase capital for the brick business.

c. The aid fund provided by BAZ which was initially only Rp. 10,000,000,- grew to Rp. $32,565,000$.

d. The development of these funds occurred because of the important role of the KBZ management with the loan mechanism provided in the amount of Rp. 1.000.000,- per member with a payback period of three months. Each member is required to pay an infaq of $10 \%$ of the loan money, which is Rp. 100,000,-. There are no special criteria for administrators in providing loans except for members who commit fraud.

e. If the borrower is unable to pay the infaq, it is not a problem because the emphasis here is on cooperation and mutual understanding. There are some members who do not return the loan money and their infaq, so the management has concluded to replace the funds into infaq.

f. Zakat aid funds, apart from providing business capital loans, are also used for social activities, such as donations to orphanages, buying mosque equipment, and hadroh equipment. 


\section{$A \mathrm{ICB} \quad$ Annual International Conference \\ on Islamic Economics and Business, 2021}

In the future, in order to develop the aid fund, the management will buy a car that will be rented out to the community for the purpose of transporting wood raw materials for making bricks.

\section{Conclusion}

- The Bina Zakat Group (KBZ) is one of the South Sumatra BAZNAS programs in the form of spreading Da'I, with the intention of empowering the community through programs to improve the quality of religious life and improve people's living standards which are carried out in a planned, continuous and integrated manner. In this KBZ, all revolving capital systems are carried out according to a predetermined agreement.

- The utilization of zakat for the economy of the Banuayu village community is very significant. The people of Banuayu Village feel the consequences in terms of business capital. So that the economy of the village community has increased and the unemployment rate can be resolved.

- The factor that causes the zakat funds to continue to grow is the application of infaq when repaying the loan. This is what makes the fund which was originally Rp. 10,000,000 has become Rp. 32,565,000. The infaq does not have any coercion because here it is purely using the principle of helping fellow members.

The suggestions related to this research are:

- The need for socialization from BAZNAS about the importance of a sense of responsibility and trust for each member of the recipient of the zakat funds.

- The need for periodic monitoring and evaluation by BAZNAS to community groups that receive productive zakat funds

- need to be adopted in other villages related to the Banuayu Village KBZ scheme which has succeeded in making zakat funds grow

- for further research it is necessary to examine $\mathrm{kbz}$ in other villages regarding the scheme used.

\section{References}

Arif, M. N. R. Al. (2010). Efek pengganda zakat serta implikasinya terhadap program pengentasan kemiskinan. Jurnal Ekbisi Fakultas Syariah UIN Sunan Kalijaga Yogyakarta, 5(1), 42-49.

Asnaini. (2008). Zakat Produktif dalam Perspektif Hukum Islam. Pustaka Pelajar.

Beik, I. S., \& Arsyianti, L. D. (2016). Ekonomi Pembangunan Syariah. Rajawali Pers.

Kholis, N., \& Mugiyati. (2021). Distribution of Productive Zakat for Reducing Urban Poverty in Indonesia. International Journal of Innovation, Creativity and Change, 15(3), 1-12.

Mochlasin, M. (2015). Community Development Dengan Instrumen Zakat Profesi Di Desa Jumoyo, Kecamatan Salam, Kabupaten Magelang. INFERENSI: Jurnal Penelitian Sosial Keagamaan, 9(1), 95-116. https://doi.org/10.18326/infsl3.v9i1.95-116

Muhammad, \& Mas'ud, R. (2005). Zakat dan Kemiskinan Instrumen Pemberdayaan Ekonomi Umat. UII Press.

Noor, J. (2016). Metodologi Penelitian: Skripsi, Tesis, Disertasi, dan Karya Ilmiah. Kencana. Qadir, A. (2001). Zakat dalam Dimensi Mahdah dan Sosial. Raja Grafindo Persada.

Qaradhawi, Y. (2005). Spektrum zakat: Dalam membangun ekonomi kerakyatan. Zikrul Hakim.

Rofiq, A. (2012). Fiqh Kontekstual: Dari Normatif ke Pemaknaan Sosial. Pustaka Pelajar. 


\section{$A \bar{C} \quad$ Annual International Conference \\ on Islamic Economics and Business, 2021}

Rosmawati, R. (2014). Pengembangan potensi dana zakat produktif melalui Lembaga Amil Zakat (LAZ) untuk meningkatkan kesejahteraan masyarakat. Padjadjaran Jurnal Ilmu Hukum, 1(1), 175-191.

Sahroni, O., Suharsono, M., Setiawan, A., \& Setiawan, A. (2018). Fikih Zakat Kontemporer. Rajawali Pers.

Sari, D. F., Beik, I. S., \& Rindayati, W. (2019). Investigating the Impact of Zakat on Poverty Alleviation: A Case from West Sumatra, Indonesia. International Journal of Zakat, $4(2), 1-12$.

Sartika, M. (2008). Pengaruh Pendayagunaan Zakat Produktif terhadap Pemberdayaan Mustahiq pada LAZ Yayasan Solo Peduli Surakarta. La_Riba: Jurnal Ekonomi Islam, 2(1), 75-89. https://doi.org/10.20885/lariba.vol2.iss1.art6 